\title{
HRM Practice and Innovative Work Behavior: Organisational Politics as Mediator and Personal Locus of Control as Moderator
}

\author{
Felix Kwame Opoku'; Innocent Senyo Kwasi Acquah² \& Kassimu Issau \\ School of Business, University of Cape Coast, Ghana \\ E-mail:felix.opoku@ucc.edu.gh ${ }^{1}$; iacquah@ucc.edu.gh ${ }^{2} ; \underline{\text { kissau@ucc.edu.gh }{ }^{3}}$ \\ https://doi.org/10.47963/jobed.2020.07
}

\begin{abstract}
The general objective of this study was to examine the effect of organisational politics on the relationship between HR practice and the innovative work behaviours of selected senior staff of the University of Cape Coast in Ghana. A secondary objective was to examine the moderation of personal locus of control on the association between organisational politics and employees innovative work behaviour. The study adopted an explanatory research design, using a purely quantitative approach. The target population comprised of all senior staff of the University of Cape Coast. The G*Power 3.1 software was used to select 119 members into the sample for this study. Data were collected through a self-administered survey questionnaire and analysed, using the Partial Least Square-Structural Equation Modelling (PLS-SEM) technique. The findings of this study suggest that organisational politics has a statistically significant positive influence on the link between human resource management practice and employees' innovative work behaviour. Unexpectedly, the paper also found that the link between organisational politics and personal locus of control, on one hand, and that between personal locus of control and innovative work behaviour, on the other hand, were statistically non-significant and negative. Therefore, we recommend that since organisational politics is an inevitable element in every human institution, any attempt by management to improve the innovative work behaviours of employees must take into account the possible effect of organizational politics on the said intervention.
\end{abstract}

Keywords: Human resource management practice, innovative work behaviour, organizational politics, personal locus of control, Ghana. 


\section{Introduction}

In the midst of the constantly changing business environment, characterised by the endless and interminable taste of customers for new products and services, one area that has become so critical to management is how to maximise the innovative potential of their employees (Pukiené, 2016). As noted by Tushman and Nadler (1986), in the $21^{\text {st }}$ Century business, there is perhaps no more pressing managerial problem than the sustained management of the innovative work behaviour of employees. Innovative work behaviour is defined by Janssen (2000) as the behaviour of an individual that is intended to intentionally create, introduce, and apply new ideas, processes, or products. Koednok and Sungsanit (2018) have recently defined innovative work behaviour as an employee's action directed at the generation, application and implementation of novelty ideas, products, processes and methods to develop their job positions, departmental units or the entire organisation. Though these definitions seem to interpret innovation as something new, including new processes, new products, new markets, new practices or a combination of any of these examples, in this study, the concept may also refer to the application of existing products or services in a unique way, as held by De-Jong and Den-Hartog (2010).

Innovative thinking is largely dependent on employee know-how (Bos-Nehles et al., 2017; Koednok \& Sungsanit, 2018). As posited by Yusuf (2009), innovation springs from the creative application of employee skills and knowledge, which, in turn, derive from the effective management of employees in the organisation. This is supported by Agarwal (2014), who argued that organisations may be restricted in their ability to innovate if they do not know how to trigger employees in a way that will encourage them to engage in innovative work behaviours. Foss and Laursen (2012) also argued in a similar manner, saying that management can improve the innovative work behaviour of their employees through dedicated training, new rewards, new ways of communicating with and between employees, and increasingly sourcing ideas and knowledge from organisational members. In sum, previous studies have shown that innovative work behaviour is achievable through the effective management of employees (BosNehles \& Veenendaal, 2019; Pukienè, 2016). There is a theoretical logic in the preceding empirical studies. The generation and implementation of creative ideas through innovative work behaviour aims at helping a firm to achieve sustainable competitive advantage over rival companies (Saá-Pérez \& Garcĺa-FalcÓn, 2002).

Among the resources in the organisation, it is only the human resource whose management meets the criteria for achieving sustainable competitive advantage (Wright et al., 1994). This conclusion is based on the resource-based theory, as proposed by Barney (1991). The central proposition of this theory, as held by Barney (1991), Wernerfelt (1984) and Prahalad and Hamel (1990), is that a firm can only achieve sustainable competitive advantage by developing such strategic resources from its own structure and within its own capabilities. It is also held that the most strategic resource of the organisation is the human resource (Prahalad \& Hamel, 1990). Consequently, the resource-based theorists believe that human resources can be managed to achieve sustainable competitive advantage since people skills and competencies are valuable, rare, non-substitutable and difficult for competitors to imitate (Saá-Pérez \& GarcÍa-FalcÓn, 2002). The emphasis on human resources has, therefore, become necessary because people hold the promise of gaining sustainable competitive advantage and innovation (Bos-Nehles et al., 2019). The innovative work behaviour of employees derives from effective HR practice (Bos-Nehles et al., 2019; Pukiene், 2016). Khan et al. (2019) identified recruitment and selection practices, training and development practices, performance appraisal practices, rewards management practices, and health and safety practices as the most common human resource management (HR) practices. The argument in this paper is that when the appropriate practices are identified and effectively implemented, the innovative work behaviour of employees will be improved (Bos-Nehles et al., 2019).

While there is a strong theoretical and empirical support for the significant positive relationship between effective HR practice and innovative work behaviour, the same cannot be said of the relevant contextual factors that mediate this relationship (Riaz \& Hussain, 2018). Furthermore, the few studies (Foss \& Laursen, 2012; Riaz \& Hussain, 2018) that tried in this direction did not consider organisational politics, which is an integral part of every organisational life (Demirel \& Goc, 2013; Ullah et al., 2011; Gotsis \& Kortezi, 2010). Thus, several questions remain unanswered as to which contextual factors more importantly affect the relationship between human resource management practice and employees' innovative work behaviour. This is the motivation for this study. Vigado-Gadot and Drory (2007) defined organisational politics as an intentional social influence process in which behaviour is strategically designed to maximise self-interests, and therefore, in conflict with the collective organisational goals or the interests of other individuals (Donald, Bertha \& Lucia, 2016; Danish, Humayon, Aslam, Usman \& Tariq, 2014). Previous studies focused on the negative aspect of organisational politics, arguing that work politics often interferes with normal organisational processes (decision making, promotion and reward) and, therefore, tends to damage productivity and performance on both the individual and organisational levels (Drory, 1993). In recent times, however, most scholars (Fedor, Maslyn, Farmer \& Betternhaasen, 2008; Simmons, 2009) have argued that if political tactics are used appropriately, they can advance an organisational cause that benefits everyone equally, then they are more likely to be seen as purposeful and legitimate.

The argument in this paper is that whereas research has found support for the positive relationship between effective HR practice and innovative work behaviour, acquiring the skills through appropriate HR practice is one 
thing, but having the feelings and commitment to put new ideas into practice is another. We suggest that, without appropriate organisational politics, HR practice can only provide the skills for innovation, but cannot assure the organisation of any meaningful innovative work behaviour. The authors are, however, aware that the influence of organisational politics on the link between human resource management practice and innovative work behaviour will not be felt exactly equally by all employees, based on their personal locus of control (Bos-Nehles et al., 2019). Spector (1982) defined personal locus of control as the degree to which individuals perceive themselves to have personal control over their environment (Rotter, 1966). Previous research has shown that the effect of organisational politics depends on the employee's personal locus of control (Spector, 1982). Employees with an internal locus of control perceive their work environments as being controllable (Agarwal, 2016). As a result, if they confront any inconvenience in their work environment, they will only change their behaviour ( $\mathrm{Ng}$ et al, 2006). Alternatively, individuals with external locus of control are less likely to change their behaviour because they do not believe that doing so would change any inconvenience in their work environment (Agarwal, 2014; Ng et al., 2006).

The main aim of this research is to investigate the effect of organisational politics on the relationship between HR practice and employees' innovative work behaviours among the senior staff of the University of Cape Coast in Ghana. A secondary objective is to examine the moderation of personal locus of control on the association between organisational politics and employees innovative work behaviour. Hence, this paper attempts to answer the following specific questions: Do HR practices directly predict employees' innovative work behaviour? and Does organisational politics significantly mediate the relationship between HR practices and employees' innovative work behaviour? In the remainder of the paper, we present the review of literature, development of hypotheses, the methodology, data presentation, discussion of results, findings and conclusions.

\section{Literature Review}

The underpinning theory of the study

The resource-based theory is the main foundation on which this study is built. It is a vital and critical theory underlying the study of strategy and competitive advantage. The theory was originally proposed by Barney (1961) and supported by several scholars, such as Ansoff (1965), Wernerfelt (1984), and Prahalad and Hamel (1990). In recent times, the theory has been refined by Hitt, Xu and Cames (2016), and Kehoe and Collins (2017). The main assumption underlying the resource-based theory is that sustainable competitive advantage derives from the internal resources and capabilities of people. These resources, according to Barney (1961), can help an organisational to achieve competitiveness only when they are rare, valuable, non-substitutable and imperfectly imitable. Among these characteristics, Barney (1961) found) the rarity of resources as the most fundamental element. He argued that a resource may be valuable, non-substitutable and imperfectly imitable during a short-term period but, if it is not rare, another organisational can easily conceive and imitate any strategy it provides, thereby reducing its value and the rate of its non-substitutability in the industry or market. Resources are rare when they are currently controlled by one company or a small number of competing companies. They are valuable when they have the ability to reduce cost or increase the price of a product or service, and they are inimitable if there is no other resource that could be used as an adequate and worthy replacement for them (Prahalad \& Hamel, 1990; Wernerfelt, 1984). Finally, resources and capabilities are non-substitutable if they do not have strategic equivalents (Bohlander, Snell \& Sherman, 2001). The resource-based theory is relevant for this study because the identification and development of employee competencies, which are part of the internal resources of the organisation, will greatly depend on the type of organisational politics in place.

\section{HR practice}

Previous studies have identified a great number of HR practices. Dessler (2005) identified selecting, screening, recruiting, training, rewarding, appraising as well as attending to labour relations, safety and health, and fairness concerns (Saifalislam, Osman \& AlQudah, 2014). Khan, Yusoff, Hussain and Binti (2019) reported recruitment and selection practices, training and development practices, performance appraisal practices, rewards management practices, and health and safety practices. Barney (2019) also reported nine practices, including recruiting, workflow, managing proficiency assessment, dismissal, compensation management, learning and development, empowerment and internationalisation, and relationships amid employees, while Theodore (2018) and Zhou (2018) identified creating a pool of suitable applicants, recruiting individuals, selecting, monitoring performance, managing compensation and training employees. Additionally, giving compensations and monitoring performance also increases the productivity of employees. Others (Bach \& Della Rocca, 2000; Vera \& Crossan 2004) have identified four practices of human resource management, including collection, selection, evolution, and compensation. Following this review, the authors of this paper have observed that there are five common HR practices, including recruitment and selection practices, training and development practices, performance appraisal practices, rewards 
management practices, and health and safety practices, as espoused by Khan et al (2019). HR practices in this study, therefore, relates to those identified by Khan et al (2019).

\section{Recruitment and selection function}

Recruitment and selection practices are the procedures used by HR managers to attract and place individuals into vacant jobs in the organisation (Khan et al., 2019). Effective recruitment and selection practices enhance the firm's chances of finding the best candidates available for any advertised position (Bartunek \& Moch, 1987). To resource an organisation, talents may be recruited internally by rehiring former employees or promoting existing employees (Taylor, 2010). Taylor (2010) believes that internal recruitment practices allow the organisation to experience cost savings in areas such as advertising, induction and training. Regardless of the benefits of internal hiring, a company may resort to external recruitment if the desired skills cannot be sourced from within. Once management has decided on how they will recruit potential candidates for the job, their next task is to select the candidate who will best fit the vacancy (Taylor, 2010). Selecting the right candidate is fundamental to the functioning of an organisation because a well-designed and implemented selection programmes produce concrete benefits, such as a reduction in turnover, and lower levels of employee misconduct (Taylor, 2010). It is for this reason that during the recruitment and selection process, management is required to ensure a better fit between the organisation and the potential employees. In doing so, management must provide job applicant with "all pertinent information (both positive and negative) without distortion." Realistic job previous (RJPs) is an alternative to the traditional "seduction" method where job candidates were only informed about the positive aspect of the organization. The realistic job previous may also be supported with appropriate testing, which are often used to screen out non-fit candidates.

\section{Training and development function}

Training and development practices consist of the procedures and methods used to by HR managers to instill learning among members of the organisation (Jacobs, 2003). While training is a short-term learning activity for the acquisition of specific skills required for doing a particular job, development equips employees with general knowledge and competencies required for future responsibilities. There are several types of training an organization can use to instil the requisite skills, knowledge and abilities in the employee. The most common classification ranges from traditional versus contemporary training, orientation versus mentorship, formal versus informal training, technical versus professional, in-house versus external training and so on (Mamoria, 1995). The type chosen depends on the availability of resources, the type of company, and the priority the company places on training. According to Ongori and Nzonzo (2011), training is frequently classified into on-the-job or off-the-job.

On-the-job training allows the trainee to develop skills in the real work situation by actually using the machinery and the materials involved in performing the job (Dessler, 2005). This type of training saves time and cost because the employee engages in the training while performing his or her daily duties concurrently. Off-the-job training occurs when trainees learn their job roles away from the actual work floor or situation, usually in an environment that is duplicated and used for that purpose (Ongori \& Nzonzo, 2011). The advantage of this type of training is that the employee does not have a divided attention. The most cited disadvantage of off-the-job training, however, is that trainees usually find it difficult to transfer the skills learnt from training to the workplace. A well-trained employee makes better and economic use of materials and equipment which, in turn, minimize wastages in the system (Mamoria, 1995). Development, on the other hand, aims at enhancing the overall growth of employees for future responsibilities (Khan et al., 2019). Training and development modify not only existing skills; they also help trainees to adapt to new technology.

\section{Performance appraisal function}

Performance appraisal practices are the HR practices by which managers evaluate, compare and provide feedback on employee performance (Ahmad \& Bujang, 2013; Fletcher, 2001). The appraisal of employee's performance is important because it serves as the basis for performance feedback and validation of selection processes, promotions and transfers (Bartunek \& Moch, 1987). Employee performance may be measured in terms of quantity or quality of output, creativity, flexibility or anything else desired by management (Campbell, 1990). The general aim of performance appraisal has always been to improve the performance of employees (Ayomikun, 2017). The term performance appraisal has many labels, including, but not limited to, performance review, employee appraisal, performance evaluation, employee evaluation, employee rating, performance assessment, performance measurement, staff assessment or personnel rating (Ahmad \& Bujang, 2013). In an effective performance appraisal system, the performance of individuals over the review period is evaluated; strengths and weaknesses identified, and reasons for any shortfall in performance examined (Bartunek \& Moch, 1987). Performance appraisal has become part of a more strategic approach for integrating HR activities and business policies, through which managers evaluate, compare and provide feedback on employee performance. An organisation can derive total benefit from the performance of her employees only when management is able to explore, expand, and appraise the full potential of their employees. 
In doing this, management must continuously review its structures and systems, create new roles, and assign new responsibilities. Again, the capability of employees to perform the new roles and responsibilities would have to be assessed.

\section{Reward and compensation function}

Reward and compensation practices are the processes and actions taken by HR managers to identify, evaluate and deliver the net monetary payments to their employees (Rana \& Malik, 2017). Appropriate compensation practices are important because most employees consider rewards as having direct bearing on their status in the organisation and the society in which the organisation operates (Ahmad \& Shahzad, 2011; Sardar et al., 2011). Employees believe that their basic pay reflects how much they fare in the organisation (Bohlander et al., 2001). The design of employee compensation is a delicate and more controversial area in human resource management. Whereas a high level of pay or benefit relative to that paid by competitors can ensure that a company attracts and retains high-quality employees, they are also likely to feel unsatisfied with their pay if what they are receiving does not reflect the time, energy, and effort they contribute to the organisation. This is the overarching reason why pay level decisions are very crucial. Generally, one of three pay policy options may be chosen: lead, lag or match policies. Firms with a lead policy pay higher wages than the average paid in the labour market. Employers who choose a lag policy pay lower than the average wage, while employers with a match policy tend to "match" the market rate. The decision to adopt any one of these strategies must depend on the ability of the firm to pay, the availability of supply of the type of labour at hand in the labour market, and the mission of the organisation.

\section{Health and safety function}

Health and safety practices are the procedures and policies taken by HR managers to maintain a safe and healthy workplace for the protection of organisational properties and the welfare of employees at work (Misnan \& Mohammed, 2007). A major challenge facing most industries today has been the prevalence of accidents resulting in injuries, diseases and loss of property and lives (Misnan \& Mohammed, 2007). According to the ILO report (2011), 160 million workers suffer from occupational diseases; more than 270 million suffer from occupational injuries; and about 2 million workers die prematurely every year from occupational illnesses (Ahmad et al., 2016; AmponsahTawiah et al., 2016). Traditionally, workplace accidents were attributed to the engineering aspect of safety. Consequently, increased efforts on engineering safety were the hallmark of the day (Thai \& Grewal, 2007; Vredenburgh, 2002).

However, in contemporary business, while accidents in industries, such as the mining, manufacturing, construction and lumber, may be due to engineering malfunctioning, the majority of accidents that occur on site may be blamed on the behavioural and social perspective of the organisation (Stemn et al, 2019; Thai \& Grewal, 2007). This implies that health and safety issues would have to be tackled from employee behaviours as well. In this regard, the concept of a safety culture becomes crucial. The U.S. Nuclear Regulatory Commission (2011) defines safety culture as an organisation's collective commitment, by leaders and individuals, to emphasise safety as an overriding priority to competing goals and other considerations to ensure protection of people and the environment (Thai \& Grewal, 2007). Thus, the attempt by management to improve the health and safety of their employees may be achieved by focusing on two aspects of the organisation - the engineering aspect and the behavioural or cognitive aspect.

\section{Organisational politics}

Gull et al. (2012) defined organisational politics as activities that permit people in an organisation to achieve goals without going through the appropriate channels. Vigoda-Gadot (2007) also defined organisational politics as behaviour that aims at safeguarding the interest of certain individuals at the expense of others. Organisational politics is also defined by Vredenburgh and Shea-VanFossen (2010) as a system that is exploited by politically skilled individuals to hasten their self-interest at the cost of another. While there are several other definitions, the fundamental tenet of organisational politics is the placement of an individual interest ahead of the interest of others, including, sometimes, the organisation itself (Aidoo et al., 2018). Again, these definitions imply that organisational politics could be detrimental to everyone except the perpetrators, thereby supporting the traditional view that organisational politics is generally characterised by destructive opportunism and dysfunctional game playing (Drory, 1993; Ferris \& Kacmar, 1992). This is often described as the dark side of organisational politics which has adverse implications for several employee outcomes, such as commitment (Donald, Bertha \& Lucia, 2016), stress (Danish, Humayon, Aslam, Usman \& Tariq, 2014), job satisfaction (Vigoda-Gadot, 2007), work performance (Bodla \& Danish, 2009) and innovative work behaviour (Elkhalil, 2017). Consequently, the attempt to improve employee innovations cannot be achieved unless it is weighed against the type of organisational politics at hand. Thus, organisational politics represents a significant aspect of human resource management (Prerna, Nikhat \& Srabasti, 2014). 
Organisational politics has taken various perspectives, largely from a behaviourist and cognitive points of view (Ferris \& Kacmar, 1992). Proponents of the behaviourist perspective believe that the propensity to engage in organisational politics is a natural characteristic of human beings, and a consequent of human evolution (Vredenburgh \& Shea-VanFossen, 2010). To the behaviourists, organisational politics is best studied from the standpoint of the nature of actual political behaviour, which often conflicts with official goals and policies (Aidoo et al., 2018; Schneider, 2016). Actual political behaviour occurs when the employee has been involved in organisational politics (Leslie \& Gelfand, 2012). The cognitive theorists hold a different view about organisational politics. According to them, organisational politics derives from the perceptions held by employees, the antecedents of such perceptions, and their consequences (Aidoo et al., 2018). Thus, the cognitive theorists believe that organisational politics is best examined by asking employees about their perceptions of politics in the work environment (Ferris \& Kacmar, 1992).

\section{Personal locus of control}

Rotter (1966) defined personal locus of control as the degree to which individuals perceive themselves to have personal control over their environment. Aldag and Stearns (1987) also defined personal locus of control as the degree to which individuals feel that the things which happen to them are the results of their own actions or others. According to the them, people who feel that such things are within their own control are described as having an internal locus of control, whereas those who see them as happening as a result of fate, circumstance or chance are described as having external locus of control. Agarwal (2016) posited that internals are likely to believe that they can do better if they put much effort, since they think the rewards and punishments they receive depend on how well they perform and not how others behave towards them. As such, internals may be more highly motivated than externals when they both face adverse organisational politics, and this can have effect on how well they would embrace innovation from their superiors (Agarwal, 2016). Thus, the inclusion of personal locus of control stem from the view that employees' response to organisational politics would greatly depend on whether they have internal or external locus of control (Agarwal, 2016).

\section{Concept of innovative work behaviour}

Farr and West (1990) defined innovative work behaviour as behaviour that aims at achieving the initiation and intentional introduction of new and useful ideas, processes, products or procedures. Innovative work behaviour is also defined by Janssen (2000) as the intentional creation, introduction and application of new ideas within a work role, group or organization, in order to benefit role performance, the group or organization. Traditionally, innovative work behaviour was used interchangeably with creativity (De Jong \& Den Hartog, 2010). However, in contemporary literature, the concept has been differentiated from creativity. This difference was highlighted by Xerri and Brunetto (2013), who stated that whereas innovative work behaviour involves the generation and implementation of ideas, creativity is limited to the generation of ideas only, and could be considered simply as a component of innovative work behaviour. Janssen (2000) identified three stages of innovative work behaviour, including (1) idea generation, (2) idea promotion and (3) idea realisations.

Idea generation involves understanding problems and identifying solutions that depart from the firms' conventional routines. In the idea promotion stage, the employee or innovator tries to promote an idea and builds a relationship with colleagues to support it. Finally, idea realisation is the ability to create a team in order to convert the innovative idea into a working and concrete object (Janssen, 2000). These stages suggest that, in contemporary business, innovative work behaviour perceived as a broad set of behaviours that are related to the generation of ideas, creating support for them and helping their implementation. Idea generation, even in the midst of the requisite support, cannot be innovative behaviour unless the idea is successfully implemented. In other words, individual innovative behaviour is not only creative; it also includes adequate promotion and the implementation of creative ideas. Creativity therefore is a necessary but not sufficient condition for innovation.

A review of the literature has shown that most studies focus on innovation at the organisational level where HR practices or systems tend to affect innovative outcomes (Koednok \& Sungsanit, 2018). However, there is the need to also focus more on how innovation can be fostered at the individual level because individuals, logically, are the holders and processors of ideas (Xerri \& Brunetto, 2013). Furthermore, individual employees can initiate innovations, because they are in frequent contact with processes and products and can detect potential improvements and opportunities for new developments (Bos-Nehles, Renkema \& Janssen, 2017).

\section{Development of hypotheses}

HR practice and innovative work behaviour

The relationship between HR practice and innovative work behaviour has received the attention of several scholars (Bos-Nehles et al, 2019; Polat, 2018; Pukienè, 2016). Pukienè (2016) investigated the role of human resource 
management in leveraging the innovative work behaviour of employees in Pakistan and found that although innovative work behaviour can be fostered by applying selective HR practices separately, it is fostered more when managers adopt a combination of HR practices. Similarly, following a desktop review of literature on human resource management and innovative work behaviour, Bos-Nehles et al. (2019) found that a combination of ability-enhancing and opportunity-enhancing HR practices helps organisations to foster the innovative work behaviour of targeted employees. The findings of other scholars (Polat, Bal, Paul \& Jansen, 2017; Bos-Nehles \& Veenedaal, 2019) produced the same or similar results. On the basis of this review, it is hypothesised that:

$H_{1}$ : There is no significant positive relationship between HR practice and innovative work behaviour.

HR practice and organisational politics

Decades of research in the humanities have shown that organisational politics exerts some influence on HR practice (Rehana et al., 2019). For instance, Drory and Vigoda-Gadot (2010) found that while organisational politics can harm the HR function, HR managers can profit from organisational politics, if they balance the negative and positive effects during selection, training, promotion and performance appraisal. In a similar study, Rehana et al. (2019) investigated the impact of nepotism and favouritism on HR practice in the public-sector hospitals in Pakistan and found that whereas nepotistic political practices affect HR practices negatively, favourable political practices affect HR practices positively. Gakure et al. (2012), however, established a weak relationship between organisational politics and management development. On this basis, it is hypothesised that:

$\mathrm{H}_{2}$ : There is no significant positive relationship between HR practice and organisational politics.

Organisational politics and innovative work behaviour

It has been established that a conducive work environment encourages the innovative work behaviour of employees (Amabile, 1988). It is also reported that a workplace that is full of adverse experiences of organisational politics, in which case employees turn to focus on ways of coping and managing the strain associated with such politics, which usually impedes the motivation to learn and acquire innovative skills and behaviours (Agarwal, 2016; Boswell, Olson-Buchanan \& LePine, 2004; Podsakoff, LePine \& LePine, 2007). For instance, Elkhalil (2017) found that the potentially destructive aspects of organisational politics have negative effect on employee innovative work behaviour among employees in the US and Lebanon. Vigoda-Gadot and Vashdi (2012) have also indicated that a work environment that is characterized by fairness, trust and openness usually enhances innovative work behaviours, but because adverse organisational politics turn to impair these attributes, they equally can impede the innovative behaviour of employees. Put differently, in the opinion of Vigoda-Gadot and Vashdi (2012), the acquisition of skills and competencies that promote innovative abilities and behaviours can be hindered amid adverse organisational politics. Based on these reviews, it is hypothesised that:

$H_{3}$ : There is no significant positive relationship between organisational politics and innovative work behaviour.

The mediation of organisational politics on the relationship between HR practice and innovative work behaviour Previous studies (Agarwal, 2016; Bos-Nehles et al., 2019; Fedor et al., 2008) suggest that organisational politics is not experienced universally by employees as a negative or threatening aspect of the workplace. Whereas the same set of employees may face the same organisational politics, the effect of those politics on the individuals may differ according to whether they have external or internal locus of control (Bos-Nehles et al., 2019). As noted by Agarwal (2016, p. 420), the ambiguity inherent in political environments leaves the situation open to interpretation by individual employees. Individuals with internal locus of control turn to interpret their work environments positively even in the midst of adverse politics, and are adept at evaluating and responding to adverse political work environments in almost the same way as if those political adversities do not exist (Erez \& Judge, 2001). These group of employees view political adversities as controllable, and they would continue to exhibit individual job attitudes and innovative work behaviours (Rotter, 1966). Alternatively, employees with external locus of control find it very stressful in coping with political adversities and innovative work behaviours (Agarwal, 2016; Ng \& Sorensen, 2008). Thus, it is hypothesised that:

$H_{4}$ : Organisational politics does not mediate the relationship between HR practice and innovative work behaviour.

The moderation of personal locus of control on the relationship between organisational politics and innovative work behaviour

Locus of control is an important variable for the explanation of organisational politics (Spector, 1982). In a study that examined the relationship between locus of control and various organisational variables, Spector (1982) found that political behaviour is a function of an employee's locus of control. Agarwal (2016) also found that because organisational politics is a social influence in which human behaviour is paramount; one cannot study organisational politics without linking it to an employee's locus of control. According to Agarwal (2016), depending on their 
personality profiles, employees do not universally respond to organisational politics. On this basis, the following hypothesis is formulated:

$H_{5}$ : Personal locus of control does not moderate the relationship between organisational politics and innovative work behaviour.

\section{Methodology}

Two corresponding methodologies, the quantitative methodology and qualitative methodology, have often been used in social science research. Quantitative research techniques gather numerical data and use statistical analysis to draw meaningful conclusions (Punch, 2005). According to Leedy and Ormrod (2010), researchers who use the quantitative research methodologies usually develop a theory by inductive reasoning, engage in a theory-building process, and try to support the theory by drawing and testing the conclusions that follow logically from the theory. Contrarily, the qualitative methodology essentially builds on interpretivism, gathering information through the use of variables measured on nominal or ordinal scale (qualitative measurement scales), and analysing data by establishing the variation in the situation, phenomenon or problem being studied without quantifying it (Kumar, 2014). The qualitative research allows the researcher to explore phenomenon by deeply relying on an interactive investigation. There is also a mixed methodology, which combines both quantitative and qualitative methodologies in a single study. It emerged from the need to conduct a research, especially in studies of human behaviour, that would provide a more complete picture of a particular phenomenon than either approach could do alone.

As the main goal of this research was to test the relationship between human resource management, organisational politics and innovative work behaviour, the authors adopted a purely quantitative approach for data collection. According to Babbie (2007), quantitative research is most appropriate when the emphasis is on measuring variables and testing hypotheses that are linked to general causal explanations.

\section{Research design}

Creswell and Clarke (2007) have identified the three primary research designs which have typically characterised social science research: exploratory, descriptive and explanatory designs. In the exploratory design, the main emphasis is on gaining ideas and insights into social reality. The exploratory design allows a researcher to identify key issues and variables in a real-world situation. The descriptive design seeks to provide accurate description of observations about a particular phenomenon, thereby helping researchers to provide similarities, comparisons and contrast between phenomena (Babbie, 2007). The explanatory design focuses on "why questions" in an attempt to understand the relationships that exist between variables (Babbie, 2007; Creswell \& Clarke, 2007). Considering the objectives and hypotheses in this study, the researchers chose the explanatory research design. This type of design provides a functional explanation of casual relationships, such as phenomenon $Y$ (e.g., income level) is affected by phenomenon $X$ (e.g., gender). It is, therefore, fit for this study.

\section{Target population and sampling procedures}

The target population for this study comprised all senior staff of the University of Cape Coast. As at the time of data collection, there were one thousand five hundred and eighteen $(1,518)$ senior staff, 931 males $(61.33 \%)$ and 587 females (28.81\%) (Directorate of Human Resource, UCC, 2017). The G*Power 3.1 software (Faul, Erdfelder \& Buchner, 2009) was used to calculate the sample size for the study. Determining the sample size for a linear multiple regression: fixed model $\left(\mathrm{R}^{2}\right.$ deviation from zero and a number of predictors equals to 3$), 119$ senior staff of the University of Cape Coast were required based on a medium effect size of 0.25 with an alpha of 0.05 and a power of 0.95 (Faul, Erdfelder \& Buchner, 2009; Faul, Erdfelder \& Lang, 2007). The G*Power is an excellent freeware program that allows high-precision power and sample size analyses. It computes power values for given sample sizes, effect sizes, and alpha levels for both post hoc and priori power analyses.

\section{Data collection and analysis}

The survey questionnaire was used to collect data for this study. The survey method was adopted because it is most appropriate for explanatory research (Yin, 2014). The anonymous nature of questionnaires allows respondents to express their inner beliefs, attitudes and perceptions freely (Cozby, 2001; Leedy \& Ormrod, 2010). Again, the method is best suited for studies that have individuals, groups and organisations as unit of analysis (Yin, 2003). Thus, considering the research approach and design of this study, the survey method was the most appropriate for achieving the study objectives. One hundred and nineteen (119) survey questionnaires were self-administered to a randomly selected senior staff of the University of Cape Coast between October 2020 and November 2020. Given the effort of the researchers and co-operation from the respondents, all the questionnaires were validly filled out and retrieved. The available data were analysed, using the structural equation modelling, which allows for simultaneous estimation of co-variation between all variables in a model (Haenlein \& Kaplan, 2004). The technique was chosen because it combines several traditional multivariate procedures and complex path models with latent variables. Again, using 
the structural equation modelling, the researcher can specify various models, such as the regression model, the confirmatory factor model, the complex path models, discriminant analysis and canonical correlation (Kim, 2016; Haenlein \& Kaplan, 2004).

\section{Measurement of constructs}

Four main constructs were measured in this study. They include HR practice, perceptions of organisational politics, personal locus of control and innovative work behaviour. For HR practice, the scales used by Demo et al. (2012) were adapted. Organisational politics were measured, using the 6-item-scale of Kacmar and Carlson (1997). Previous studies by Karadal and Arasli (2009) have demonstrated that the scales have satisfactory psychometric properties. Personal locus of control was measured by using the 23-item scale of Engelbrecht (2012). Innovative work behaviour was measured, using the 4-item scale of Radaelli et al. (2014). All the items were scored on a Five-Point Likert Scale with anchors $1=$ Least Agreement, and $5=$ highest Agreement.

\section{Results of the Study}

Measurement model assessment

The study assessed item loadings, construct reliability and validity, average variance extracted and discriminant validity in order to determine the appropriateness of the measurement model for the structural model to ensue. According to Henseler et al. (2015), the assessment of the aforementioned is to provide clear meaning of the structural model results.

\section{Item Loading}

The item loadings assessed the quality of the indicators, measuring each construct within the context of the study. In its determination, the indicator loadings of each construct were examined. Based on the rule of thumb, items with loadings $\geq 0.70$ or between 0.4 and 0.7 indicated a quality measure of their respective constructs (Henseler et al., 2015). In this regard, only items that met the set criteria were retained in the model, as depicted in Table 1.

Table 1: Outer loadings

\begin{tabular}{|c|c|c|c|c|}
\hline OUTER LOADINGS & HRMP & IWB & LOC & OP \\
\hline hrmppp & 0.734 & & & \\
\hline hrmpr & 0.889 & & & \\
\hline hrmprc & 0.810 & & & \\
\hline hrmptd & 0.708 & & & \\
\hline$i w b 1$ & & 0.752 & & \\
\hline$i w b 2$ & & 0.830 & & \\
\hline$i w b 3$ & & 0.690 & & \\
\hline$i w b 4$ & & 0.534 & & \\
\hline locl & & & 0.798 & \\
\hline loc11 & & & 0.747 & \\
\hline loc12 & & & 0.814 & \\
\hline loc2 & & & 0.841 & \\
\hline loc 3 & & & 0.811 & \\
\hline loc4 & & & 0.728 & \\
\hline loc6 & & & 0.726 & \\
\hline loc7 & & & 0.738 & \\
\hline loc 8 & & & 0.782 & \\
\hline $\operatorname{loc} 9$ & & & 0.781 & \\
\hline popl & & & & 0.763 \\
\hline pop2 & & & & 0.809 \\
\hline
\end{tabular}

Construct reliability

The indicator reliability of the model was measured, using Cronbach's alpha and Joreskog's rho-A (@) scores. According to Hair et al. (2019), the scores of the two measures should be $>0.70$ in order to ensure satisfactory and acceptable results. As shown in Table 2, the requirements of the two measures have been met for all constructs except 
organisational politics which had a score less than 0.7 . The Composite Reliability (CR) values were also presented in Table 2. The CR values show that all indicators when put together had a score of 0.6 to 0.7 (Hair et al., 2019). Thus, the constructs were sufficiently measured by their indicators when put together. Also presented in Table 2 are the results of the Average Variance Extracted (AVE). The AVE values show that the measurement model is best for the structural analysis to ensue, as all the latent variables were not less than 0.5 (Hair et al., 2019).

Table 2: Construct Reliability

\begin{tabular}{lllll}
\hline Constructs & $\begin{array}{l}\text { Cronbach's } \\
\text { Alpha }\end{array}$ & rho_A & $\begin{array}{l}\text { Composite } \\
\text { Reliability }\end{array}$ & $\begin{array}{l}\text { Average } \\
\text { Extracted (AVE) }\end{array}$ \\
\hline HRMP & & & & \\
IWB & 0.667 & 0.701 & 0.799 & 0.504 \\
LOC & 0.928 & 0.943 & 0.938 & 0.605 \\
OP & 0.383 & 0.385 & 0.764 & 0.618 \\
\hline
\end{tabular}

Discriminant validity

Discriminant validity indicates how the constructs are distinct from each other. According to Sarstedt et al. (2014), discriminant validity is appropriate for a measurement model when the Heterotrait-Monotrait (HTMT) ratio of the model is $<0.85$. The results of HTMT, as depicted in Table 3 , show that the constructs are distinct from each other.

Table 3: Discriminant Validity (Heterotrait-Monotrait Ratio)

\begin{tabular}{lllll}
\hline HRMP & Original Sample (O) & Sample Mean (M) & $\mathbf{5 . 0 \%}$ & $\mathbf{9 5 . 0 \%}$ \\
\hline LOC -> IWB & 0.261 & 0.288 & 0.203 & 0.383 \\
OP -> IWB & 0.673 & 0.716 & 0.498 & 0.936 \\
OP -> LOC & 0.154 & 0.219 & 0.122 & 0.358 \\
\hline
\end{tabular}

Assessment of the structural model

The significance level of path coefficients $(\beta)$ was examined, using t-statistics and P-values obtained through 5000 bootstraps, as recommended by Hair et al. (2019). The results are shown in Table 4. The results revealed that HR practices had a positive and significant relationship with both innovative work behaviour ( $\beta: 0.544$; P-value:0.005) and organisational politics ( $\beta: 0.380 ; \mathrm{P}$-value:0.027). However, the relationship between HR practices and innovative work behaviour ( $\beta: 0.544$; P-value:0.005) is greater compared with the relationship between HR practice and organisational politics ( $\beta: 0.380$; P-value:0.027). Furthermore, significant positive relationship was established between organisational politics and innovative work behaviour ( $\beta: 0.144$; P-value:0.024). Conversely, the relationships between locus of control and innovative work behaviour ( $\beta$ : - $0.044 ; \mathrm{P}$-value:0.362) and organisational politics and locus of control ( $\beta$ : - -0.068 ; P-value:0.389) were negative and non-significant.

Table 4: Structural model assessment

\begin{tabular}{lllll}
\hline & Paths (Beta) & T Statistics & P Values & $\mathbf{F}^{\mathbf{2}}$ \\
\hline HRMP -> IWB & 0.544 & 2.834 & 0.005 & 0.384 \\
HRMP -> OP & 0.380 & 2.213 & 0.027 & 0.169 \\
LOC -> IWB & -0.044 & 0.913 & 0.362 & 0.003 \\
OP -> IWB & 0.144 & 2.260 & 0.024 & 0.029 \\
OP -> LOC & -0.068 & 0.861 & 0.389 & 0.005 \\
& & & & $\mathbf{Q}^{\mathbf{2}}$ \\
Innovative Work Behaviour & & & $\mathbf{R}^{\mathbf{2}}$ & 0.187 \\
Organisational Politics & & & 0.392 & 0.083 \\
Locus of Control & & 0.144 & 0.002 \\
\hline
\end{tabular}

The results in Table 4 further indicated that HR practice contributes $39.2 \%$ of the changes in the innovative work behaviour. With this result, it can be concluded that $60.8 \%$ of the variations in the innovative work behaviour is accounted by extraneous variables. Also, $14.4 \%$ of the changes in organisational politics is accounted by HR practices. Similarly, $0.5 \%$ of the variations in the locus of control is explained by organisational politics. In the view 
of Hair et al. (2019), the effect size $\left(\mathrm{f}^{2}\right)$ and predictive relevance $\left(\mathrm{Q}^{2}\right)$ values of each exogenous variable of $0.35,0.15$ and 0.02 indicate large, medium and small, respectively. In line with this criterion, HR practice was established to have large and medium effect sizes on innovative work behaviour and organisational politics, respectively. However, the remaining nexuses of the study (Table 4) only established small effect sizes. This indicates that HR practice is a major determinant of changes in innovative work behaviour. In addition, the predictive relevance values shown in Table 4 reiterates the position that HR practice best explains the variations in innovative work behaviour. The results are also shown in Figure 1.

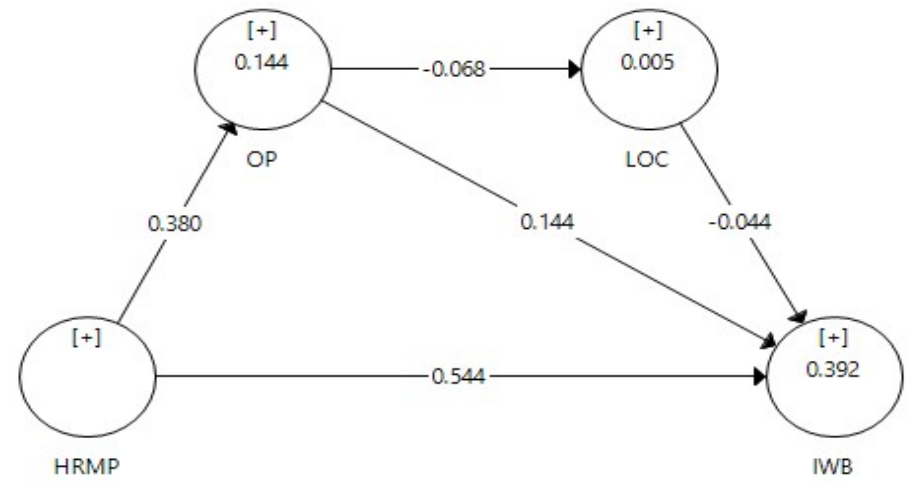

Figure 1: The structural equation model for the study

\section{Discussion of Results}

Previous studies have shown that HR practice has significant positive influence on employees' innovative work behaviour (Bos-Nehles et al., 2019; Foss \& Laursen, 2012; Koednok \& Sungsanit, 2018; Polat, 2018). While research seems to abound in this area of study, there are only few studies (Foss and Laursen, 2012; Riaz \& Hussain, 2018) that attempted to investigate the effect of contextual factors on the relationship between HR practice and employees' innovative work behaviour. Thus, questions remain as to which contextual factors more importantly affect the relationship between HR practice and employees' innovative work behaviour. This paper examines the effect of organisational politics on the relationship between HR practice and employees' innovative work behaviour. A further look at the mediation of personal locus of control on the relationship between organisational politics and employees' innovative work behaviour was considered. The discussion of results is based on five headings, reflecting the five hypotheses in the study.

\section{HR practice and Innovative work behaviour}

The results in Table 4 and Figure 1 show that HR practice has a significant positive influence on employees' innovative work behaviour ( $\beta: 0.544$; P-value:0.005). The positive coefficient ( $\beta: 0.544)$ implies that as HR practices improve, the innovative work behaviour of employees also improves in the same direction. Five HR practices were important in this study - recruitment and selection practices, employee attraction and retention practices, training and development practices, performance appraisal practices, rewards and compensation practices, as well as health and safety practices. By extension, the results in Table 4 show that a positive change in these practices would lead to a positive change in employees' innovative work behaviour. As the p-value $(0.005)$ is less than 0.05 , the relationship between HR practice and employees' innovative work behaviour is declared significant, meaning that the hypothesis, "There is no significant positive relationship between HR practice and innovative work behaviour," is rejected in this study.

The preceding results are in line with previous studies (Koednok \& Sungsanit, 2018; Polat, 2018; Pukienè, 2016), which reported that innovative work behaviour of employees can be fostered both by adopting selective HR practices and/or combining such practices. The results also support the findings of Bos-Nehles et al. (2019) and Bos-Nehles and Veenedaal (2017) that employees' innovative work behaviour is largely dependent on a combination of abilityenhancing HR practice (the use of recruitment and selection, training and development practices to increase the competencies of employees to achieve organisational goals), motivation-enhancing HR practice (the use of contingent rewards such as performance-based-pay, piece rate systems, profit sharing systems and performance management practices to increase the employees' motivation to perform) and opportunity-enhancing HR practices (practices that delegate decision making authority and responsibility from top level hierarchy to lower level hierarchy through information sharing). These results also imply that, in order to improve the innovative work behaviours of employees through HR practice, the HR manager has the responsibility of ensuring that the HR function comprises ability-enhancing, motivation-enhancing and opportunity-enhancing components. 


\section{HR practice and organizational politics}

The study further examined the relationship between HR practice and organizational politics. As in Table 4 and Figure 1, the results show that there is a statistically significant positive relationship between HR practice and perceptions of organisational politics ( $\beta: 0.380$; P-value:0.027; $\left.\mathrm{R}^{2}: 0.144\right)$. The positive coefficient ( $\left.\beta: 0.380\right)$ implies that as management engages in effective HR practices; there would be improvement in the positive aspect of workplace politics. Again, as the p-value (0.027) is less than 0.05 , the relationship between HR practice and organisational politics is declared significant, meaning that the null hypothesis, "There is no significant positive relationship between HR practice and organisational politics, " is rejected. By implication, the results indicate that managers who intend to improve the skills, Knowledge and abilities of their employees through HR practices, such as recruitment and selection, employee attraction and retention, training and development, performance appraisal, compensation and health and safety practices, must ensure that the existing organisational politics can support those interventions, otherwise the employees may acquire all the skills and knowledge, but fail to apply them, because they think the existing organisational politics does not favour them. These results are consistent with earlier studies (e.g., Drory \& Vigoda-Gadot, 2010; Rehana et al., 2019), that perceptions of organisational politics have both positive and negative influence on HR practices, depending on how HR managers handle the situation. Thus, whereas organisational politics can harm the HR function, HR managers can profit from it, if they strategically manage the negative and positive effects of organizational politics during employee recruitment, selection, training, promotion and performance appraisal. The results, however, are not consistent with the findings of Gakure et al. (2012), who found a very weak relationship between HR practice and organisational politics.

\section{Organisational politics and innovative work behaviour}

This study further examined the relationship between organisational politics and employees' innovative work behaviour. The results in Table 4 ( $\beta: 0.144$; P-value:0.024) show that organisational politics has a statistically significant positive influence on employees' innovative work behaviour (see Figure 1 and Table 4). The positive coefficient ( $\beta: 0.144)$ implies that as the existing organisational politics favours the employees, they would not have to worry about negative political setbacks, which, in turn, would eliminate any adverse effect of organisational politics on their innovative work behaviour. As the p-value (0.024) is less than 0.05 , the relationship between organisational politics and employees' innovative work behaviour is declared significant, meaning that the null hypothesis, "There is no significant positive relationship between organizational politics and innovative work behaviour," is rejected. These results imply that organisations that are able to adopt appropriate work politics can ensure improvements in the innovative work behaviour of their employees. As a result, HR managers must ensure that their HR practices work towards curtailing any adverse political behaviour or the subjective perception of the dark side of work politics among members in the organisation. These results corroborate the findings of previous studies (Agarwal, 2016; Boswell, Olson-Buchanan \& LePine, 2004; Baxter, 2004; Clarke \& Higg, 2019; Elkhalil, 2017; Podsakoff, LePine \& LePine, 2007), that negative organisational politics can curtail employee innovativeness as it can impede the motivation to learn new skills and ideas. Thus, in practice, any attempt to improve the innovativeness of employees must be checked against the prevailing workplace politics.

\section{HR practice, organisational politics and innovative work behaviour}

The main focus of this study was to assess the effect of organisational politics as a contextual factor in the relationship between HR practice and innovative work behaviour. As a result, the authors examined the mediation of organisational politics on the relationship between HR practice and innovative work behaviour. It was found that the links between HR practice and organisational politics ( $\beta$ : 0.380; P-value: 0.027$)$, on one hand, and organisational politics and innovative work behaviour ( $\beta$ : 0.144 ; P-value: 0.024$)$, on the other hand, were statistically significant and positive (see Figure 1 and Table 4). The positive coefficients ( $\beta: 0.380)$ and( $\beta: 0.144)$ imply that organisational politics has significant influence on the link between HR practice and innovative work behaviour of employees. Again, as each of the p-values (P-value: 0.027) and (P-value: 0.024) is less than 0.05, the relationship among HR practice, organisational politics and innovative work behaviour is declared significant, meaning that the null hypothesis, "Organizational politics mediates the relationship between HR practice and innovative work behaviour," is rejected. In other words, organisational politics has a significant positive influence on the relationship between HR practice and employees' innovative work behaviour. These results are in line with previous studies (Bos-Nehles et al., 2019; Erez \& Judge, 2001), that in the midst of adverse organisational politics, employees who have external locus of control are demotivated from learning and demonstrating innovative skills and behaviours. Alternatively, those with internal locus of control do not exhibit similar behaviours (Agarwal, 2016; Ng \& Sorensen, 2008). 
Organisational politics, personal locus of control and innovative work behaviour

The study also sought to examine whether personal locus of control moderates the relationship between organisational politics and innovative work behaviour. Unexpectedly, it was found that the links between organisational politics and personal locus of control ( $\beta$ : -0.068; P-value: 0.389), on one hand, and personal locus of control and innovative work behaviour ( $\beta$ : -0.044; P-value: 0.362 ), on the other hand, were statistically nonsignificant and negative (see Figure 1 and Table 4). In other words, personal locus of control does not moderate relationship between organisational politics and employees' innovative work behaviours. As a result, the null hypothesis that "Personal locus of control does not moderate the relationship between organisational politics and innovative work behaviour" is supported. There is, therefore, a contradiction between the results of this study and previous studies (Agarwal, 2016; Spector, 1982), that political behaviour is a function of an employee's locus of control. In other words, internals and externals universally respond to organisational politics in the same way and in the same direction. Perhaps, this may be due to cultural variations between the western and developing countries. The instruments might have contained some cultural elements, which could not have been interpreted the same way in different cultures. The contradiction between the results of this study and previous studies may also be attributed to the fact that most of the respondents had external locus of control, which this study could not assess before their selection into the sample.

\section{Conclusion}

This study was conducted to investigate the effect of organisational politics on the relationship between HR practice and innovative work behaviour of employees. Organisational politics is an inevitable element in both public and private sector organisations. It is an inherent part of people and organisational management, and, therefore, cannot be left out in any study about employee behaviour at the workplace. The extant literature and findings of this study support the fact that organisational politics mediates the link between HR practice and innovative work behaviour. The results of this study also support previous studies, that organisational politics has a strong effect on employees' innovative work behaviours. These revelations confirm the idea that management cannot improve the innovative work behaviour of employees, unless they diligently assess the effect of organisational politics on their HR practices, and the effects of any adversities of workplace politics on employee innovativeness. In this way, this study has answered the question of whether there are contextual factors, mitigating the positive effect of HR practice on the innovative work behaviour of employees, as consistently found in previous studies. These results have important managerial implications. Management of higher educational institutions, including universities and colleges, must lay more emphasis on the link among HR practice, organisational politics and innovative work behaviour. The ability of management to use effective HR practices for leveraging the innovative work behaviours of their employees may be impeded unless the appropriate work politics is in place.

On whether personal locus of control has significant effect on the link between organisational politics and employees' innovative work behaviour, the results of this study were in contrast with previous findings. Unlike previous studies, the study found that personal locus of control is equally experienced by both externals and internals and, therefore, has no effect on the link between organisational politics and employees' innovative work behaviour. Thus, future research may assess the state of respondents' locus of control, then compare the behavioural effect of each of the two groups (internals and externals) on the link between organisational politics and employees' innovative work behaviour. Future studies may also examine the effect of personal locus of control on the relationship between organisational politics and the innovative work behaviour of employees in other sectors of the economy, since this study was conducted among staff of higher educational institutions. 


\section{References}

Agarwal, U. A. (2014). Linking justice, trust and innovative work behaviour to work engagement. Personnel Review, 23(1), $41-73$.

Agarwal, U. A. (2016). Examining perceived organizational politics among Indian managers. International Journal of Organizational Analysis, 24(3), 415 - 437.

Ahmad, I., Sattar, A., \& Nawaz, A. (2016). Occupational health and safety in industries in developing world. Gomal Journal of Medical Sciences, 14(4), 223 - 228.

Ahmad, R., \& Bujang, S. (2013). Issues and challenges in the practice of performance appraisal activities in the 21st century. International Journal of Education and research, 1(4), 1-8.

Ahmad, S., \& Shahzad, K. (2011). HRM and employee performance: A case of university teachers of Azad Jammu and Kashmir (AJK) in Pakistan. African journal of business management, 5(13), 5249-5253.

Aidoo, E. (2018). Effect of employee morale on productivity in the Ghanaian public sector. The mediating role of delegation. Archives of Business Research, 6(8), 365 - 375.

Aldag, R. \& Stearns, T. (1987). Management. Cincinnati: South-Western Publishing Co.

Amabile, T.M. (1988). A model of creativity and innovation in organizations. In B.M. Staw \& L.L. Cummings (Eds.), Research in organizational behaviour, 10, 123 - 167).

Amponsah-Tawiah, K., Ntow, M. A. O., \& Mensah, J. (2016). Occupational health and safety management and turnover intention in the Ghanaian mining sector. Safety and Health at Work, 7(1), 12 - 17.

Ansoff, H. I. (1965). Corporate strategy: Business policy for growth and expansion. McGrawHill.

Ayomikun, I. (2017). Effectiveness of performance appraisal system and its effect on employee motivation. Nile Journal of Business and Economics, 5, 15 - 39.

Babbie, E. (2007). The practice of social research: International student edition (11 ${ }^{\text {th }}$ ed.). Australia: Wadsworth Cengage Learning.

Bach, Stephen, \& Rocca, D. (2000). The management strategies of public service employers in Europe. Industrial Relations Journal, 31(2), 82 - 96.

Barney, J. (1991). Firm resources and sustained competitive advantage. Journal of management, 17(1), 99-120.

Barney, J. (2019). Firm resources and sustained competitive advantage. Journal of Management, 17(1), 99 - 120.

Bartunek, J. M., \& Moch, M. K. (1987). First-order, second-order, and third-order change and organization development interventions: A cognitive approach. The Journal of Applied Behavioral Science, 23(4), 483 - 500.

Bodla, M. A. \& Danish, R. Q. (2009). Politics and workplace: An empirical examination of the relationship between perceived organisational politics and work performance. South Asian Journal of Management, 16(1), 44 - 58.

Bohlander, G., Snell, S., \& Sherman, A. (2001). Managing human resources (12th ed.), South-Western College Publishing, Australia

Bos-Nehles, A. C., \& Veenendaal, A. A. (2019). Perceptions of HR practices and innovative work behaviour: The moderating effect of an innovative climate. The International Journal of Human Resource Management, 30(18), $2661-2683$.

Bos-Nehles, A., Bondarouk, T., \& Nijenhuis, K. (2017). Innovative work behaviour in knowledge-intensive public sector organizations: The case of supervisors in the Netherlands fire services. The International Journal of human resource management, $28(2), 379$ - 398.

Boswell, W.R., Olson-Buchanan, J.B. \& LePine, M.A. (2004). Relations between stress and work outcomes: The role of felt challenge, job control, and psychological strain. Journal of Vocational Behaviour, 64(1), 165 - 181.

Campbell, J. P. (1990). Modeling the performance prediction problem in industrial and organizational psychology, In M. D. Dunnette, \& L. M. Hough (Eds), Handbook of industrial and organizational psychology ( $2^{\text {nd }}$ ed.). Palo Alto, CA: Consulting Psychology Press.

Cozby, P. C. (2001). Methods in behavioural research ( $7^{\text {th }}$ ed.). Boston: McGraw-Hill.

Creswell, J. W., \& Clarke, V. L. (2007). Designing and conducting mixed methods research. Thousand Oak, CA: Sage.

Danish, R., Humayon, A. Aslam, N., Usman, A. \& Tariq, M.I. (2014). Employee's perceptions of organizational politics and stress at workplace: A comparative study of public and private sector universities. Research Journal of Recent Sciences, 3(7), 44 - 52.

De Jong, J., \& Den Hartog, D. (2010). Measuring innovative work behaviour. Creativity and Innovation Management, 19(1), 23 - 36.

Demirel, Y., \& Goc, K. (2013). The impact of organizational commitment on knowledge sharing. In 1st Annual International Interdisciplinary Conference (pp. 954-963).

Demo, G., Neiva, E. R., Nunes, I., \& Rozzett, K. (2012). Human resources management policies and practices scale (HRMPPS): Exploratory and confirmatory factor analysis. BAR-Brazilian Administration Review, 9(4), 395 420.

Dessler G. (2005). Human resource management (10th Ed). Pearson Prentice Hall: USA 
Directorate of Human Resource Management, UCC (2017). Documentation and Information Section. Desk Diary, Cape Coast.

Donald, M. F., Bertha, L. \& Lucia, M.E. (2016). Perceived organizational politics influences on organizational commitment among supporting staff members at a selected higher education institution. The 2016 WEI International Academic Conference Proceedings, 16(2), 29 - 37.

Drory, A. (1993). Perceived political climate and job attitudes. Journal of Organisation Studies, 14, 59 - 71.

Drory, A., \& Vigoda-Gadot, E. (2010). Organizational politics and human resource management: A typology and the Israeli experience. Human Resource Management Review, 20(3), 194 - 202.

Elkhalil, Y. A. (2017). Organizational politics and employee behavior: A comparison between the US and Lebanon. Doctorate thesis submitted to the College of Management and Technology, Walden Organisation.

Engelbrecht, C. (2012). Determining the construct validity of Udai Pareek's locus of control inventory (Doctoral dissertation submitted to the University of Pretoria).

Erez, A. \& Judge, T.A. (2001). Relationship of core self-evaluations to goal setting, motivation, and performance. Journal of Applied Psychology, 86(6), 270 - 285.

Farr, J. L., \& West, M. A. (Eds.). (1990). Innovation and creativity at work: Psychological and organizational strategies. Wiley, Chichester.

Faul, F., Erdfelder, E., Buchner, A., \& Lang, A. G. (2009). Statistical power analyses using G* Power 3.1: Tests for correlation and regression analyses. Behavior Research Methods, 41(4), 1149-1160.

Faul, F., Erdfelder, E., Lang, A. G., \& Buchner, A. (2007). G*Power 3: A flexible statistical power analysis program for the social, behavioural, and biomedical sciences. Behavior Research Methods, 39(2), 175 - 191.

Fedor, D., Maslyn, J., Farmer, S. \& Betternhausen, K. (2008). The contribution of positive politics to the prediction of employee reactions. Journal of Applied Social Psychology, 38, 76 - 96.

Ferris, G.R., \& Kacmar, K.M. (1992). Perceptions of organizational politics. Journal of Management, 93 - 116.

Fletcher, C. (2001). Performance appraisal and management: The developing research agenda. Journal of Occupational and Organizational Psychology, 74(4), 473 - 487.

Foss, N., \& Lausen, K. (2012). Human resource management practices and innovation. In Handbook of Innovation Management, Oxford Organisation Press.

Gakure, R. W., Orwa, G., \& Wachira, F. N. (2012). The impact of organizational politics on the effectiveness of management development in the Kenya civil service. International Journal of Business and Social Research, 2(5), $250-259$.

Gotsis, G. N., \& Kortezi, Z. (2010). Ethical considerations in organizational politics: Expanding the perspective. Journal of Business Ethics, 93(4), 497 - 517.

Gull, S., \& Zaidi, A. A. (2012). Impact of organizational politics on employees' job satisfaction in the health sector of Lahore Pakistan. Interdisciplinary Journal of Contemporary Research in Business, 4(2), 156 - 170.

Haenlein, M., \& Kaplan, A. M. (2004). A beginner's guide to partial least squares analysis. Understanding Statistics, 3(4), $283-297$.

Hair, J. F., Risher, J. J., Sarstedt, M., \& Ringle, C. M. (2019). When to use and how to report the results of PLS-SEM. European Business Review, 31(1), 2 - 24.

Henseler, J., Ringle, C. M., \& Sarstedt, M. (2015). A new criterion for assessing discriminant validity in variancebased structural equation modeling. Journal of the Academy of Marketing Science, 43(1), 115 - 135.

Hitt, M.A., Xu, K., \& Cames, C.M. (2016). Resource-based theory in operations management research. Journal of Operations Management, 4l(1), 107 - 109.

Jacobs, J. (2016). The death and life of great American cities. Vintage. New York: Random House.

Janssen, O. (2000). Job demands, perceptions of effort-reward fairness and innovative work behaviour. Journal of Occupational and Organizational Psychology, 73(3), 287 - 302.

Kacmar, K. M., \& Carlson, D. S. (1997). Further validation of the perceptions of politics scale (POPS): A multiple sample investigation. Journal of Management, 23(5), 627 - 658.

Karadal, H., \& Arasli, H. (2009). The impacts of superior politics on frontline employees' behavioural and psychological outcomes. Social Behavior and Personality: An International Journal, 37(2), 175 - 190.

Kehoe, R. R., \& Collins, C. J. (2017). Human resource management and unit performance in knowledge-intensive work. Journal of Applied Psychology, 102(8), 1222 - 1236.

Khan, M. A., Md Yusoff, R., Hussain, A., \& Binti Ismail, F. (2019). The mediating effect of job satisfaction on the relationship of HR practices and employee job performance: Empirical evidence from higher education sector. International Journal of Organizational Leadership, 8, 78 - 94.

Koednok, S., \& Sungsanit, M. (2018). The influence of multilevel factors of human resource practices on innovative work behavior. The Journal of Behavioral Science, 13(1), 37 - 55.

Kumar, R. (2014). Research Methodology: A Step-by-Step Guide for Beginners, 4 Pap/Psc edition. Sage Publications Ltd 
Leedy, D. P., \& Ormrod, J. E. (2010). Practical research: Planning and design ( $9^{\text {th }}$ ed.). Boston: Pearson Education International.

Leslie, L. M., \& Gelfand, M. J. (2012). The cultural psychology of social influence: Implications for organizational politics. Politics in Organizations: Theory and Research Considerations, 411 - 447.

Mamoria, C.B. (1995). Personnel management. Himalaya Publishing House. New Delhi.

Misnan, M. S., \& Mohammed, A. H. (2007, November). Development of safety culture in the construction industry: A strategic framework. In Conference on Sustainable Building South East Asia (Vol. 5, p. 7).

Misnan, M.S. \& Mohammed, A.H. (2007). Development of safety culture in the construction industry: A strategic framework. Conference on sustainable building, South East Asia.

Ng, T. W., Sorensen, K. L., \& Eby, L. T. (2006). Locus of control at work: A meta-analysis. Journal of Organizational Behavior, 27(8), 1057-1087.

Ongori, H., \& Nzonzo, J. C. (2011). Training and development practices in an organization: An intervention to enhance organizational effectiveness. International Journal of Engineering and Management Sciences, 2(4), $187-198$.

Podsakoff, N.P., LePine, J.A. \& LePine, M.A. (2007). Differential challenge stressor-hindrance stressor relationships with job attitudes, turnover intentions, turnover, and withdrawal behaviour: A meta-analysis. Journal of Applied Psychology, 92(2), 43 - 58.

Polat, T. P., Bal, M., \& Paul G. W Jansen, P. G. W. (2017). How do development HR practices contribute to employees' motivation to continue working beyond retirement age? Work, Aging and Retirement, 3, 366 378.

Prahalad, C. K., \& Hamel, G. (1990). The core competence of the corporation. Harvard Business Review, 68(3), 79 91.

Prerna, C., Nikhat, A. \& Srabasti, C. (2014). The impact of perceived organisational politics on work attitudes: The moderating role of leadermember-exchange quality. International Journal of Human Capital and Information Technology Professionals, 5(2), 1 - 13.

Pukienè, A. (2016). Innovative work behavior: The role of human resource management and affective commitment. Master's thesis submitted to ISM Organization of Management and Economics, Pakistan.

Punch, K. F. (2005). Introduction to social research: Quantitative and qualitative approaches (2 ${ }^{\text {nd }}$ ed.). London: Sage Publications Inc.

Radaelli, G., Lettieri, E., Mura, M., \& Spiller, N. (2014). Knowledge sharing and innovative work behaviour in healthcare: A micro-level investigation of direct and indirect effects. Creativity and Innovation Management, 23(4), 400 - 414.

Rana, M. H., \& Malik, M. S. (2017). Impact of human resource (HR) practices on organizational performance. International Journal of Islamic and Middle Eastern Finance and Management, 10(2), 186 - 207.

Rehana, Y., Munaza, B. \& Raza, A (2019). Impact of organization politics on human resource management practices and employee performance. SEISENSE Journal of Management, 2(2), 39 - 47.

Riaz, S., Xu, Y., \& Hussain, S. (2018). Understanding employee innovative behavior and thriving at work: A Chinese perspective. Administrative Sciences, 8(3), 46 - 54.

Rotter, J. B. (1966). Generalized expectancies for internal versus external control of reinforcement. Psychological Monographs: General and Applied, 80(1), 1 - 14.

Saa-Perez, P. D., \& Garcia-Falcon, J. M. (2002). A resource-based view of human resource management and organizational capabilities development. International Journal of Human Resource Management, 13(1), 123 140.

Saifalislam, K. M., Osman, A \& AlQudah, M.K (2014). Human resource management practices: Influence of recruitment and selection, and training and development on the organizational performance of the Jordanian Public University. IOSR Journal of Business and Management (IOSR-JBM), 16(5), 43 - 46.

Sardar, S., Rehman, A., Yousaf, U., \& Aijaz, A. (2011). Impact of HR practices on employee engagement in banking sector of Pakistan. Interdisciplinary Journal of Contemporary Research in Business, 2(9), 378 - 389.

Sarstedt, M., Ringle, C.M., Smith, D., Reams, R. \& Hair, J. FHair Jr, J. F. (2014). Partial least squares structural equation modeling (PLS-SEM). European Business Review, 5(1), 105 - 115.

Schneider, R. C. (2016). Understanding and managing organizational politics, 2(1), 697 - 709.

Simmons, B.L. (2009). Negative effects of bad politics at work. Academy of Management Journal, 52(6), 74 - 89.

Spector, P. E. (1982). Behaviour in organizations as a function of employee's locus of control. Psychological Bulletin, 91(3), $482-493$.

Stemn, E., Bofinger, C., Cliff, D. \& Maureen, E. (2019). Investigating the maturity of incident investigations of the Ghanaian mining industry and its effect on safety performance, Safety, $1-25$.

Taylor, S. (2010). Resourcing and talent management Chartered Institute of Personnel Development, London. 
Thai, V. V., \& Grewal, D. (2007). The maritime security management system: Perceptions of the international shipping community. Maritime Economics \& Logistics, 9(2), 119 - 137.

Theodore, J. (2018). Absence of transformational leadership in Greek enterprises results in the inability of forming learning organizations. The International Business \& Economics Research Journal, 12(6), 701 - 714.

Tushman, M., \& Nadler, D. (1986). Organizing for innovation. California Management Review, 28(3), 74 - 92.

Ullah, S., Jefri, R. A., \& Dost, B. K. M. (2011). A synthesis of literature on organisational politics. Far East Journal of Psychology and Business, 3(3), 36 - 49.

Vera, D. \& Crossan, M. (2004). Strategic leadership and organizational learning. Academy of Management Review, $29(2), 222-240$.

Vigoda-Gadot, E. (2007). Leadership style, organizational politics, and employees' performance. Personnel Review, $36(5), 661-683$.

Vigoda-Gadot, E.; Vashdi, D.R. (2012). Politics in and around teams: Toward a team-level conceptualization of organizational politics. In politics in organizations: Theory and research considerations; Ferris, G.R., Treadway, D.C., Eds.; Routledge: New York, NY.

Vredenburgh, A. G. (2002). Organizational safety: Which management practices are most effective in reducing employee injury rates? Journal of Safety Research, 33(2), 259 - 276.

Vredenburgh, D., \& Shea-VanFossen, R. (2010). Human nature, organizational politics, and human resource development. Human Resource Development Review, 9(1), 26 - 47.

Wernerfelt, B. (1984). A resource-based view of the firm. Strategic Management Journal, 5(2), 171 - 180.

Wright, P. M., McMahan, G. C., \& McWilliams, A. (1994). Human resources and sustained competitive advantage: A resource-based perspective. International Journal of Human Resource Management, 5(2), 301 - 326.

Xerri, M. J., \& Brunetto, Y. (2013). Fostering innovative behaviour: The importance of employee commitment and organizational citizenship behaviour. The International Journal of Human Resource Management, 24(16), 3163 $-3177$.

Yin, R. K. (2014). Case study research: Design and methods (5th ed.) Thousand Oaks, CA: Sage.

Yusuf, J. (2009). From creativity to innovation. Technology in Society, 31(1), 1 - 8.

Zhou, T. (2018). Understanding continuance usage of mobile sites. Industrial Management and Data Systems, 113(9), $1286-1299$. 